\title{
A Study on the Impact of Yoga Tourism on Tourists Visiting Kerala
}

\author{
Ambili K*
}

Abstract

Yoga tourism is the latest trend which includes both treatments as well as tourism. Kerala has emerged as the most acclaimed yoga tourist destination in the world. This study delineates the major reasons that increase the suitability of Kerala for yoga practice, the source of information about destinations in Kerala, the kind of tourism which are preferred to be combined with yoga trips, and how long have the tourists been doing yoga in their lives and the impact of yoga in their lives. The study was carried out by a descriptive research design based on survey method. Averages, percentages, chi-square test and factor analysis were used for analyzing the study. The result showed that traditional system of yoga was the major reason for suitability of Kerala for yoga practices, friends, relatives and travel agents remain key persons in giving information to the yoga tourists, and yoga has a high positive impact on tourists' lives.

Keywords: Yoga tourism, yoga practice, yoga tourists, destination, traditional system

* Guest Lecturer, Department of Travel and Tourism Management, T K M College of Arts and Science, Kollam, Kerala, India; ambilinandu@rediffmail.com 


\section{Introduction}

Varieties of tourism products make Kerala, God's Own Country as one of the most acclaimed tourist destinations in the world. Tourism in Kerala is propelled by the presence of beaches, backwaters, hill stations, waterfalls, wildlife, healthcare products, art forms, festivals, unique climatic conditions, and rich flora and fauna. Among these, health tourism has a major share in Kerala. Health care resources of Kerala include Modern Medicine like Allopathy and Holistic System of Medicine such as Yoga, Ayurveda, Homeopathy, Unani, Siddha, and Naturopathy. In recent years, there is a growing demand for therapies like Yoga in Health Tourism and this modern day phenomenonhas led to Kerala becoming a hub of Yoga Retreats. Kerala's natural beauty, salubrious climate, culture and traditional system of yoga make it a most preferred destination for Yoga Tourism.

Yoga an ancient Indian culture has been practiced for more than 5000 years. Yoga means the union of body, mind, and spirit. As an activity, it is one of the fastest growing pursuits in Kerala. Yoga is not a religion, but it is meant for individual growth and physical, emotional, intellectual and spiritual balance (Iyengar,1989). It is a perfectly structured and integrated worldview aiming at the transformation of a human being from his actual unrefined form to a perfect form. It is a system of balancing and harmonizing the different aspects of being, including the consciousness, the body the mind, the emotional and the spiritual elements. It improves posture, increases the intake of oxygen and enhances the functioning of the respiratory, digestive, endocrine, reproductive and excretory systems. It particularly produces remedies as well as preventive measures for illnesses such as stress, strain, tension, psychic irritation and inability to understand the ways of life.

\section{Literature Review}

Yoga Tourism is relatively a new phenomenon. Today tourists visit Kerala for rejuvenating their mind and body.

As far as medical treatment is concerned, it must be acknowledged that modern science is valuable and that yoga can be used in 
conjunction with other scientifically sound medical treatments (Sharma, et al., 2008). Scientific studies on Yoga show that it offers health benefits beyond general fitness. Early results suggested that it can provide relief for patients suffering from asthma, chronic back pain, arthritis and obsessive-compulsive disorder, among other problems (Pope, 2002). For many individuals, yoga has become the centerpiece in their pursuit for a balanced life. For some people practicing yoga constitutes the central theme of their vacation (Letho, et al., 2006). Kerala has enormous potentials to become one of the world's best health tourism destinations, and the state is blessed with a wide variety of tourism attractions and health care infrastructure (Jyothis, et al., 2009). Attracted by yoga, tourists from various countries such as United States, Canada, Europe, Australia and the Middle East are coming to Kerala.

The review of available literature shows that very little work has been done on yoga related to tourism. This study aims at analyzing the impact of yoga on tourists' lives and the major reasons for the suitability and choice of Kerala as a place to practice yoga.

\section{Objectives of the Study}

- Identifying the factors that enhance the suitability of Kerala for yoga practices.

- Evaluating the sources of information about destinations in Kerala, and which form of tourism is usually preferred to be combined with a yoga trip.

- Analyzing how long the tourists have been doing yoga and the impact of yoga on their lives.

\section{Data and Methodology}

Primary data and Secondary data were used for the analysis. The primary data collection was done by canvassing a study questionnaire in randomly selected yoga centers, all over Kerala state. The present study was based on the feedback of 300 yoga tourists, both domestic and foreign. Structured questionnaires were used for collecting data from the respondents. The secondary data has been collected from various sources such as books, newspapers, journals, etc. The Methodology used was descriptive research 
methodology, for which statistical tools such as Percentages, ChiSquare test, and Factor analysis were used. The main applications of factor analysis are: (1) to reduce an original set of variables into a smaller set of non-correlated components that represent most of the information found in the original variables, and (2) to detect structure in the relationships between variables, thereby classifying the variables. By reducing the dimensionality, it is possible to interpret a few components rather than a large number of variables.

\section{Research Findings}

\section{Major Reasons for Suitability of Kerala for Yoga Practices}

Percentage analysis was used as a research tool to assess the suitability of Kerala for yoga. Four factors namely, 'Natural Beauty', 'Tourism attractions', 'Traditional system of yoga' and 'Ayurveda and Naturopathy' were examined.

Table - 1

\begin{tabular}{|l|c|}
\hline Suitability of Kerala & Percentage \\
\hline Natural beauty & 27.0 \\
\hline Tourism attractions & 3.7 \\
\hline Traditional system of yoga & 64.7 \\
\hline Ayurveda and Naturopathy & 32.3 \\
\hline
\end{tabular}

The ancient marvel of yoga is a priceless art inKerala, which has been practiced by the people of Kerala for centuries. The analysis shows that about 64.7 percent of the tourists believe that Kerala is suitable for yoga practices because of the traditional system of yoga in Kerala. 32.3 percent said Kerala is suitable because of the Ayurveda and Naturopathy practices in the state. 27 percent said that Kerala is suitable because of the natural beauty. And only 3.7 percent of them said that the suitability is because of the other tourist attractions in Kerala. Hence most of the yoga tourists believe that traditional system of yoga is the major reason for suitability of Kerala for yoga practice. 


\section{Sources of Information about Destinations in Kerala}

Table - 2

\begin{tabular}{|l|c|}
\hline Source of Information & Percentage \\
\hline Tourism Department of your State/ Country & 15.3 \\
\hline Tourist information center of Govt. of India & 6.3 \\
\hline Kerala tourism department & 16.3 \\
\hline Travel agents & 39.0 \\
\hline Official Kerala websites & 28.0 \\
\hline Relatives/Friends & 59.3 \\
\hline Others & 12.0 \\
\hline
\end{tabular}

The study revealed that 59.3 percent of the tourists got the information from relatives or friends; it is followed by 39 percent who got information from travel agents. Official websites of the Kerala government contributed to 28 percent of the total information. Thus, it is evident that friends, relatives, and travel agents are key players' tourists rely on for information.

\section{Which Type of Tourism is Preferred to be Combined with Yoga Trips}

Table -3

\begin{tabular}{|l|c|}
\hline Particulars & Percentage \\
\hline Cultural tourism & 57.3 \\
\hline Medical tourism & 81.7 \\
\hline Eco-tourism & 37.3 \\
\hline Backwater tourism & 51.7 \\
\hline Beach tourism & 61.3 \\
\hline Heritage tourism & 40.0 \\
\hline Mountain tourism & 15.3 \\
\hline Wildlife tourism & 20.0 \\
\hline MICE tourism & 2.3 \\
\hline Adventure tourism & 13.3 \\
\hline Fairs and Festivals & 24.0 \\
\hline
\end{tabular}

A question regarding the combination of other Tourism packages along with a yoga tourism package was asked to the respondents, with a motive to find out the opinion of tourists. The opinions regarding each attraction are recorded separately and then 
consolidated into one Table. Out of 100 percent, about 81 percent of the tourists opted that yoga tourism should be combined with medical tourism, as a single package. 61 percent respondents felt that yoga tourism should be combined with beach tourism. It is followed by cultural Tourism (57.3 percent), backwater tourism (51.7 percent) and heritage tourism (40 percent) in third, fourth and fifth places respectively.

\section{Years of Experience in practicing Yoga}

Table -4

\begin{tabular}{|c|c|c|c|c|c|c|}
\hline \multirow[b]{2}{*}{ Nationality } & \multicolumn{4}{|c|}{ Experience in Yoga Practices } & \multirow[b]{2}{*}{ Total } & \multirow[b]{2}{*}{$\begin{array}{c}\text { Chi- } \\
\text { square }\end{array}$} \\
\hline & $\begin{array}{c}\text { More } \\
\text { than } \\
\text { 5years }\end{array}$ & $\begin{array}{l}1 \text { to } 5 \\
\text { years }\end{array}$ & $\begin{array}{c}1-12 \\
\text { months }\end{array}$ & $\begin{array}{c}\text { Less } \\
\text { than one } \\
\text { month }\end{array}$ & & \\
\hline Domestic & 15.3 & 50.7 & 26.0 & 8.0 & 100.0 & \multirow{2}{*}{12.105} \\
\hline Foreign & 28.7 & 45.3 & 14.7 & 11.3 & 100.0 & \\
\hline Total & 22.0 & 48.0 & 20.3 & 9.7 & 100.0 & \\
\hline
\end{tabular}

The analysis shows that most of the yoga tourists had started practicing yoga early because they had realized the preventive and curative aspects of yoga. The domestic tourists (50.7\%) have the highest percentage of 1 to 5 years of practice, and also the least percent $(8.0 \%)$ of those who are recently practicing yoga.

A hypothesis is tested to find out if there is any difference in the duration of yoga practice between domestic and foreign tourists. The null hypothesis states that there is no significant difference in the duration of yoga practice between foreign and domestic tourists. A Chi-square test was carried out to check if the difference is significant. Chi-square test showed that the observed value was 12.105, at degrees of freedom 3 and chi-square table value of 7.815. Since the observed value of the chi-square is greater than the table value, the null hypothesis is rejected. Hence it is observed that foreign tourists are more consistent in practicing yoga than domestic tourists.15.3 percent of domestic tourists are practicing yoga for more than five years, while it is 28.7 percent in the case of foreign tourists. Most of the domestic tourists start practicing yoga regularly, and drop it in between 1 to 5 years. 


\section{The Impact of Yoga on Tourists' Lives}

\section{The Prominent Factors of Yoga that impact Tourists' Lives}

Thirteen variables were used for the study to assess the prominent factors. The thirteen variables are:

1. Understanding the fundamental principles of yoga

2. Building a relaxed, balanced, and healthy life

3. Meeting and interacting with people with similar interests

4. Learning to look at life differently

5. Improving mental functioning and calm mind

6. Reducing destructive habits

7. Helps not to get angry

8. Helps not to feel anxious

9. Yoga brings spirituality

10. Yoga brings physical and mental health

11. Yoga brings emotional balance

12. Yoga brings holistic harmony to mind and body

13. One of the best yoga tourism destination in the world The percentage analysis showed that all the factors had positive impacts rather than negative impacts on practicing yoga. Two factors namely 'Yoga brings physical and mental health' (86.7) and 'Yoga brings holistic harmony to mind and body' (79.7) had got the highest responses with high positive impact. 'One of the best yoga tourism destinations in the world' had got the least percent of highly positive impact option with 21.7 percent.

\section{Factor Analysis}

Factor analysis is carried out to identify the most prominent impact of yoga in tourists' lives. For this purpose, dimension reduction method is used, in which the variability of the data is analyzed due to each variable and then the variables because of which most of the data is affected are identified. 
To find out the significant number of factors affecting the 13 variables, Eigen Values for the factors are calculated. Since there are 13 variables, we assume that 13 independent unobservable factors, at the maximum, affect the 13 variables, in which each factor may have a unique effect on each 13 variables. After calculating the Eigen Values, it is found that up to the fourth factor, the Eigen Values are greater than 1. Therefore using the Kaiser's criterion the first four factors are selected. In normal situations, Kaiser's method is used for selecting the factors. That is the number of factors affecting the data reduces to 4 . The first four factors together are responsible for 64 percent of the variability in the data. The Eigen Values associated with each factor represent the variance explained by that particular factor. Analyzing these Eigen Values, we can choose the factors from the 13 factors for further analysis.

A solution for the linear relationship between the observed variables to the factors is found using the linear equation solving methods involving the selected factors. After finding the solution to the linear relationship, the solution is rotated so as to maximize the variance of each factor selected. Rotation is doneto identify the degree of relationship of each factor to the observed variables. The solution matrix is also called the factor loadings matrix.

Rotated Component Matrix

Table -7

\begin{tabular}{|l|r|r|r|r|}
\hline \multirow{2}{*}{ Results of Doing Yoga Regularly } & \multicolumn{4}{|c|}{ Component } \\
\cline { 2 - 5 } & 1 & 2 & 3 & 4 \\
\hline $\begin{array}{l}\text { Understanding the fundamental } \\
\text { principles of yoga }\end{array}$ & .153 & .301 & -.074 & .750 \\
\hline $\begin{array}{l}\text { Build up a relaxed, balanced, and } \\
\text { healthy life }\end{array}$ & .278 & .504 & .048 & .061 \\
\hline $\begin{array}{l}\text { Meeting and interacting with } \\
\text { people with similar interest }\end{array}$ & .206 & .103 & .710 & .079 \\
\hline Learning to look at life differently & .167 & .031 & .765 & .111 \\
\hline $\begin{array}{l}\text { Improves mental functioning and } \\
\text { calm mind }\end{array}$ & .613 & .163 & .324 & .050 \\
\hline Reducing destructive habits & .053 & .253 & .682 & .027 \\
\hline Helps to not get angry & .848 & .270 & .148 & .002 \\
\hline Helps to not feel anxious & .848 & .204 & .067 & .023 \\
\hline Yoga brings spirituality & .663 & .098 & .099 & .439 \\
\hline
\end{tabular}




\begin{tabular}{|l|r|r|r|r|}
\hline $\begin{array}{l}\text { Yoga brings physical and mental } \\
\text { health }\end{array}$ & .401 & .683 & .115 & .173 \\
\hline Yoga brings emotional balance & .193 & .691 & .365 & .285 \\
\hline $\begin{array}{l}\text { Yoga brings holistic harmony to } \\
\text { mind and body }\end{array}$ & .282 & .743 & .107 & -.058 \\
\hline $\begin{array}{l}\text { One of the best yoga tourism } \\
\text { destination in the world }\end{array}$ & .019 & -.075 & .387 & .674 \\
\hline
\end{tabular}

The above table is the rotated solution of the factor loadings. In the solution, each factor has a value of loading for the observed variables. Some factors have high loadings to some variables and low loadings to others. Factors with high loading show the very strong relation of the factors to the variables. The highest loadings of the factors are highlighted in the table. Using this, all 13 variables are groupedinto four major groups according to the factor loadings value that is shown in the following table.

Grouping of Variables

Table -8

\begin{tabular}{|c|c|c|}
\hline Factor & Variables & $\begin{array}{l}\text { Corresponding } \\
\text { Factor Loading }\end{array}$ \\
\hline \multirow{4}{*}{1} & Improves mental functioning and calm mind & .613 \\
\hline & Helps to not get angry & .848 \\
\hline & Helps to not feel anxious & .848 \\
\hline & Yoga brings spirituality & .663 \\
\hline \multirow{4}{*}{2} & Build up a relaxed, balanced and healthy life & .504 \\
\hline & Yoga brings physical and mental health & .683 \\
\hline & Yoga brings emotional balance & .691 \\
\hline & $\begin{array}{l}\text { Yoga brings holistic harmony to mind and } \\
\text { body }\end{array}$ & .743 \\
\hline \multirow{3}{*}{3} & $\begin{array}{l}\text { Meeting and interacting with people with } \\
\text { similar interest }\end{array}$ & .710 \\
\hline & Learning to look at life differently & .765 \\
\hline & Reducing destructive habits & .682 \\
\hline \multirow{2}{*}{4} & $\begin{array}{l}\text { Understanding the fundamental principles } \\
\text { of yoga }\end{array}$ & .750 \\
\hline & $\begin{array}{l}\text { One of the best yoga tourism destination in } \\
\text { the world }\end{array}$ & .674 \\
\hline
\end{tabular}


The variables used were classified into four major groups using the principal component analysis. Each group represented an underlying factor. For the first factor, there were four variables having the highest factor loadings. Among them 'helps not to get angry' and 'helps not to feel anxious' have the highest values. Similarly from second, third and fourth factors 'yoga brings holistic harmony to mind and body', 'learning to look at life differently' and 'understanding the fundamental principles of yoga' have the highest loadings respectively. These four factors can be used to describe the group of 13 variables in this rating. That is, the four variables represent the group of 13 variables andare the most important factors that can impact tourists' lives.

\section{Results and Discussions}

Percentage analysis revealed that most of the yoga tourists believed that traditional system of yoga was the major reason for suitability of Kerala for yoga practices. Friends, relatives, and travel agents are key people in giving information about destinations to tourists. Most of the tourists opted that yoga tourism should be combined with medical tourism as a single package. Beach tourism has also got good support from the respondents to becombined with yoga tourism. Percentage analysis showed that most of the tourists had been practicing yoga for the last 1 to 5 years. This showed that most of the yoga tourists had started early in practicing yoga because they realized the preventive and curative aspects of yoga.

The results of factor analysis revealed that four variables represented the group of 13 variables: 'helps not to get angry, 'helps not to feel anxious,' 'yoga brings holistic harmony to mind and body,' 'learning to look at life differently' and 'understanding the fundamental principles of yoga.' Through the analysis, it is realized that these are the most important factors that impacted tourists' lives.

\section{Conclusions and Suggestions}

The analysis explained major reasons for suitability of Kerala for yoga practice, and the tourist's duration of yoga practice. It revealed that a traditional system of yoga being practiced in the 
state is the major reason for suitability of Kerala for yoga practice. Also, starting to practice yoga at an early age, and doing it for more than 1-5 years are two other factors that induce tourists choice of Kerala as their preferred tourist destination. It was also learned that tourists receive information about their travel destinations from friends, relatives, and travel agents. Four variables were revealed by factor analysis as the major impacting factors in tourists' lives.

Introducing more awareness programs about the suitability of Kerala for yoga practices would increase the flow of tourists into Kerala. More marketing techniques to be undertaken and improve the supporting facilities that may increase yoga tourist's visit to Kerala. Encourage authentic yoga centers and quality trainers to attract a large number oftourists to Kerala. These measures would enable Yoga tourism to contribute to the destination community of Kerala and the Kerala Government.

\section{References}

Iyengar, B. K., \& Rivers-Moore, D. (1989). The tree of yoga : Yoga vrksa. Boston: Shambhala.

Jyothis, T., \& Janardhanan, V. K. (2009). Kerala as a Health Tourism Destination: SWOT Analysis, South Asian Journal of SocioPolitical Studies (SAJOSPS), 9 (2), pp. 151-154.

Letho, X. Y., Brown, S., Yichen \& Morrison, A. M. (2006). Yoga Tourism as a Niche within the Wellness Tourism Market. Tourism Recreation Research, 31(1), p. 26.

Pope, P. T.( 2002). The Health Benefits of Yoga, Doctors Study, The Wall Street Journal.

Sharma, V., Tomar, R. S., \&Ahola, N. N. (2008, May). Branding India for health and spiritual Tourism. Health, Spiritual and Heritage tourism. Conference on Tourism in India-Challenges Ahead, IIMK, p. 470. 